DOI: $10.46340 /$ eujem.2020.6.6.5

\author{
Liubov Drozdovska \\ ORCID: https://orcid.org/0000-003-3029-9851 \\ Ivan Franko National University of Lviv, Ukraine

\section{EVALUATION OF STAFFING \\ OF THE EDUCATIONAL ACTIVITIES \\ IN THE SPHERE OF HIGHER EDUCATION IN UKRAINE}

This article presents evaluation of staffing in the system of higher education in Ukraine based on the analysis of statistical reporting. There have been made evaluation of the structure of academic staff of the higher school and the changes in their numbers, indices of activity of postgraduate and doctorate programs, focusing on the defense of thesis research works in the fields of knowledge and their comparison with the changes in the demand of prospective students for higher education. Based on the results of such evaluation the need has been outlined to improve the principles and approaches to the formation of staff potential of higher school taking into consideration the needs of human resources in sectoral markets.

Key words: higher education, staffing of higher education, academic staff of higher school, teaching staff, academic teaching personnel, academic specialists, postgraduate studies, doctorate studies.

Problem statement. To ensure compliance with the requirements of the state standards in the course of activities in the sphere of higher education, higher educational establishments (HEE) must possess a complex of resources whose integral part is the staff component. Undoubtedly staffing policy must be oriented towards organization of the effective educational, scientific, managerial and financial-economic activity, but the key task is the task of the formation of staff composition involved in the educational process producing a qualitatively new workforce and supplying economy of the country with highly-skilled professionals.

Analysis of the latest studies and publications. The problems of the formation, use and development of performance potential of the higher education establishments (HEE) are elucidated in the works of O. Pochtovyuk, M. Terovanesov, A. Rybnikov, O. Kolesnyk, O. Skibytska, O. Obmok, O. Rezvan. The essence and content of educational and scientific potential of the higher education system in general and teacher training college has been described by I. Stepanets in his works. However, there is still no actual formulation of a comprehensive and systemic nature of staffing in the higher school and thus some of the aspects of this issue require a separate scientific study taking into consideration its problematical character and importance.

The purpose of this article is assessment, determination of particularities and regularities of the formation and tendencies of the development of staffing in the system of strategic priorities in the development of higher education in Ukraine.

Statement of key material. Academic staff of the higher school is formed by the teaching, academic teaching and scientific personnel which is specified in Article 53 of the Law of Ukraine "On higher education".

"1. Academic teaching employees are persons who carry on educational, methodological, scientific (scientific and technical, artistic) and organizational work in the HEE on the full-time basis.

2. Teaching employees are persons who carry on educational, methodological and organizational work in the HEE on the full-time basis.

3. Academic employees are persons who carry on scientific, technical or scientific-organizational work professionally under a labor contract (agreement) on the full-time basis and have an appropriate qualification whether having or not having an academic degree or academic title."1

\footnotetext{
1 Закон Украӥни про вищу освіту, 2014 (Верховна Рада України). Офіційний сайт Верховної Ради Украӥни <https://zakon.rada.gov.ua/laws/show/1556-18\#Text2> (2020, September, 20).
} 
Academic and academic teaching employees aside from the participants of educational process at the same time are the subjects of scientific and technical activity. Even before 2019 the State Committee for Statistics of Ukraine did not take into account the data on academic employees when assessing the academic staff of the higher school. However, the Law of Ukraine "On scientific and scientific-technical activity" clearly describes the relation of an academic specialist to the teaching activity: academic specialist is a scientist who has a higher education above the second level (Master's degree), carrying on scientific, scientific-technical, scientific-organizational, scientific-teaching activity professionally under a labor contract (agreement) and has an appropriate qualification whether having or not having an academic degree or academic title, confirmed by the results of certification in cases provided for by the laws ${ }^{1}$.

There is an inconsistence as to what education establishments we attribute to the HEE. The Law of Ukraine "On higher education" determines such types of the HEE as universities, academies, institutes, colleges2. The latter, according to the Law of Ukraine "On professional pre-higher education", are attributed to the professional pre- HEE 3. In 2019 colleges, junior colleges and technical schools for the last time admitted students for the junior specialist degree as for a level of higher education, before that they were attributed in the reports of the State Statistical Service of Ukraine to the HEE with indication of the level of accreditation.

Analysis of staffing in the higher education requires assessment of a great amount of data (Table 1). The network of the establishments and the body of those who obtain higher education require a top-priority analysis.

As we see, intentions of the government officials to reduce the number of HEE are confirmed by the transformations taking place in this sphere despite the insignificant increase of the number of HEE of I-II and III-IV levels of accreditation by $0.6 \%$ in 2017/2018 compared to 2016/2017 academic year.

The 2019/2020 academic year was characterized by the large-scale downsizing by $5.6 \%$. This concerned the closure and merging of colleges, junior colleges and technical schools $-8.6 \%$. Universities, academies and institutes experienced greater changes in the previous year, when their number fell by $2.4 \%$.

However, the number of students studying in the HEE decreased steadily during 2015-2018, though in the last 2019/2020 academic year there was a significant negative jump of this value by 5.4\%.

Despite the continuous talks about the reduction of the number and merger of the HEE of the III-IV levels of accreditation their number does not fall drastically. On the contrary, they are in greater demand among the perspective students, and the reduction of the number of students here is not significant: the lowest in $2016 / 2017$ academic year $-0.4 \%$, and the highest $-4.2 \%$ in $2019 / 2020$ academic year. Such trends are caused not only by reduction of the number of HEE, but also by the economic and demographic situation and by their growing popularity of choice among the perspective students of foreign HEE.

Reforming of higher education is impossible without participation and teaching support of the HEE staff that pertains more to their creative potential. The fact, that in 2019 the State Committee for Statistics of Ukraine in its analytical reports assessing teaching staff of higher school took into account the data on academic specialists, had an effect on the increase of this index in 2019/2020 academic year by $2.6 \%$. The weight of influence of academic specialists on this index was $3.95 \%$.

In the period from 2015 to 2018 one instructor had an average of 10 students. In educational establishments with a higher level of accreditation one instructor had one student more. Reduction of the number of students in comparison with the downsizing of the teaching staff last year was more dramatic, therefore the number of students decreased to 9 . This can be explained by inclusion in the teaching staff of HEE the category of academic specialists.

If, according to the "License Conditions for Educational Activities of Educational Establishments" the number of members of the teaching staff is sufficient provided, that it corresponds to the ratio of 30 seekers for higher education of all levels, courses and forms of studies (except online - no more than 60)

\footnotetext{
1 Закон Украӥни про наукову і науково-технічну діяльність, 2016 (Верховна Рада України). Офіиійний сайт Верховної Ради Украӥни <https://zakon.rada.gov.ua/laws/show/848-19\#Text > (2020, September, 20).

2 Закон України про вищу освіту, 2014 (Верховна Рада України). Офіційний сайт Верховної Ради Украӥни <https://zakon.rada.gov.ua/laws/show/1556-18\#Text2> (2020, September, 20).

3 Закон України про фахову передвищу освіту, 2019 (Верховна Рада України). Офіиійний сайт Верховної Ради України <https://zakon.rada.gov.ua/laws/show/2745-19\#Text > (2020, September, 20).
} 
Table 1

\section{Key indices of academic staff and the body of higher education seekers overtime (2014/2015-2019/2020 academic years)}

\begin{tabular}{|l|c|c|c|c|c|}
\hline & $2015 / 2016$ & $2016 / 2017$ & $2017 / 2018$ & $2018 / 2019$ & $2019 / 2020$ \\
\hline $\begin{array}{l}\text { HEE of I-II levels of accreditation } \\
\text { (colleges, technical high schools) }\end{array}$ & 371 & 370 & 372 & 370 & 338 \\
\hline $\begin{array}{l}\text { HEE of III-IV levels of accreditation } \\
\text { (universities, academies, institutes) }\end{array}$ & 230 & 217 & 209 & 200 & 174 \\
\hline students in them, thousand persons & 1375 & 1369 & 1330 & 1322 & 1266 \\
\hline Academic specialists, total number & - & - & - & - & 6049 \\
\hline $\begin{array}{l}\text { working in HEE of I-II levels } \\
\text { of accreditation, persons }\end{array}$ & - & - & - & - & 83 \\
\hline $\begin{array}{l}\text { working in HEE of III-IV levels } \\
\text { of accreditation, persons }\end{array}$ & 111878 & 110396 & 108101 & 106765 & 105984 \\
\hline Academic teaching workers, total number & 152 & 341 & 328 & 325 & 1274 \\
\hline $\begin{array}{l}\text { working in HEE of I-II levels } \\
\text { of accreditation, persons }\end{array}$ & 111726 & 110055 & 107773 & 106440 & 104710 \\
\hline $\begin{array}{l}\text { working in HEE of III-IV levels } \\
\text { of accreditation, persons }\end{array}$ & 51017 & 49333 & 48236 & 46212 & 44876 \\
\hline Teaching staff, total number & 28512 & 27435 & 26626 & 25618 & 22093 \\
\hline $\begin{array}{l}\text { working in HEE of I-II levels } \\
\text { of accreditation, persons }\end{array}$ & 22505 & 21898 & 21610 & 20594 & 22783 \\
\hline $\begin{array}{l}\text { working in HEE of III-IV levels } \\
\text { of accreditation, persons }\end{array}$ & 659 & 657 & 661 & 652 & 619 \\
\hline HEE (as at the start of academic year) & 1605 & 1506 & 1539 & 1522 & 1440 \\
\hline students in them, thousand persons & 28664 & 27776 & 26954 & 25643 & 23450 \\
\hline $\begin{array}{l}\text { Academic staff in HEE of I-II levels } \\
\text { of accreditation, total number }\end{array}$ & 131953 & 129383 & 127034 & 133459 \\
\hline $\begin{array}{l}\text { Academic staff in HEE of III-IV levels } \\
\text { of accreditation, total number }\end{array}$ & 159729 & 156337 & 152977 & 156909 \\
\hline Academic staff in HEE, total number & - & - & - & 5966 \\
\hline
\end{tabular}

Source: produced by the author on the basis of ${ }^{1}$

in relevant speciality per one instructor, then the load on the group of educational work is even too small ${ }^{2}$. But it should be borne in mind that academic case of a higher school instructor may contain up to 5 disciplines. The norms of the number of students per one full-time post of the academic teaching employee differ for each speciality, educational level and the form of studies $^{3}$, and a member of the teaching group of one specialty may be included in the teaching group of other speciality in the same educational establishment, which will

\footnotetext{
${ }^{1}$ Державна служба статистики України (2020). Статистичні збірники Вищза освіта в Украӥні за 2015-2019 рр. <https://ukrstat.org/uk/druk/publicat/kat_u/publosvita_u.htm> (2020, September, 20

${ }^{2}$ Постанова про внесення змін до постанови Кабінету Міністрів Украӥни від 30 грудня 2015 р. № 1187

“Про затвердження Ліцензійних умов провадження освітньої діяльності закладів освіти”, 2018

(Кабінет міністрів України). Офіційний сайт Верховної Ради Украӥни <https://zakon.rada.gov.ua/laws/show/ 347-2018-\%D0\%BF\#Text>(2020, September, 20).

${ }^{3}$ Постанова про нормативи чисельності студентів (курсантів), аспірантів (ад'юнктів), докторантів, здобувачів наукового ступеня кандидата наук, слухачів, інтернів, клінічних ординаторів на одну штатну посаду науково-педагогічного прачівника у вищих навчальних закладах III і IV рівня акредитації та вищих навчальних закладах післядипломної освіти державної форми власності, 2002 (Кабінет міністрів України). Офіиійний сайт Верховної Ради України <https://zakon.rada.gov.ua/laws/show/1134-2002-\%D0\%BF\#Text> (2020, September, 20).
} 
increase the amount of classroom and out-of-class workload. That being said, the need for the full-time posts for carrying on the educational process is determined proceeding from the standard of working time of educational work of teaching, academic teaching and scientific staff of the HEE, depending on the academic degree and academic title of the instructor.

Dynamics of qualitative composition of the academic teaching staff shows that from year to year the number of doctors of sciences though slightly, but grows. If in 2015/2016 the number of instructors with an academic degree attained $65.4 \%$, in 2019/2020 academic year their number increased up to $70.6 \%$. Their age composition has a tendency towards ageing. The numerical composition of the younger people under 30 years employed in this sphere falls, and if in 2001 there were $22.5 \%$ of them, in $2007-18.8 \%$, in 2018 their number fell to $15.4 \%$ despite the fact, that a sufficiently effective institute of postgraduate and doctoral studies (Fig. 1 and 2) formed by the HEE and by the scientific establishments functions in Ukraine.

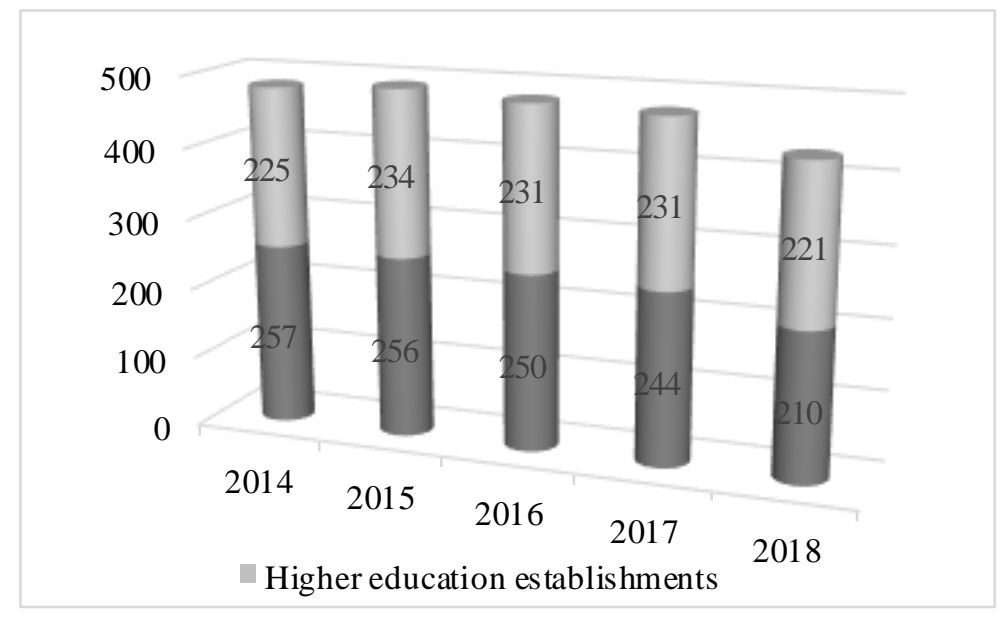

Fig. 1. Network of establishments with postgraduate programs (2014-2018)

Source: produced by the author on the basis of ${ }^{1}$

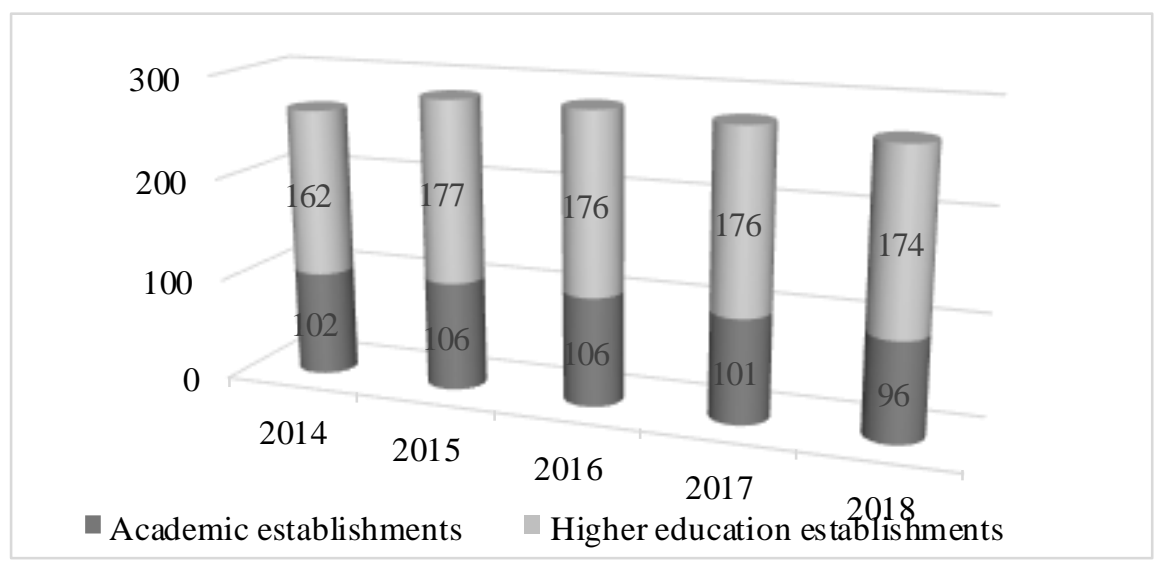

Fig. 2. Network of establishments with doctoral programs (2014-2018)

Source: Developed by the author on the basis of

\footnotetext{
${ }^{1}$ Державна служба статистики України (2020). Статистичні збірники Наукова та інноваційна діяльність в Україні за 2014-2018 pp. <http://www.ukrstat.gov.ua/druk/publicat/Arhiv_u/16/Arch_nay_zb.htm>(2020, September, 20). ${ }^{2}$ Ibid.
} 
The number of national universities training postgraduate students is higher than the number of HEE, and the number of them training doctoral students, on the contrary, is smaller. There is a negative trend of reducing the number of national universities that train the academic degree seekers, but both, in quantitative terms and percentage-wise the total number: postgraduate students $-53.3 \%$ in 2014 and $48.7 \%$ in 2018 ; doctoral students $-38.6 \%$ in 2014 and $35.6 \%$ in 2018 . As to the HEE, despite the reduction of their number, their share in the general structure grows: postgraduate students $-46.7 \%$ in 2014 and $51.3 \%$ in 2018; doctoral students $-61.6 \%$ in 2014 and $64.4 \%$ in 2018 .

The largest number of postgraduate students study in the HEE despite their small share in the total number. The same situation is with the training of doctors of sciences (Table 2).

Table 2

\section{Key indices of activity of postgraduate and doctoral training in Ukraine}

(2014-2018)

\begin{tabular}{|l|c|c|c|c|c|}
\hline & 2014 & 2015 & 2016 & 2017 & 2018 \\
\hline $\begin{array}{l}\text { Number of postgraduate students, } \\
\text { total persons }\end{array}$ & 27622 & 28487 & 25963 & 24786 & 22829 \\
\hline National universities, persons & 4129 & 3862 & 3125 & 2652 & 2080 \\
\hline $\begin{array}{l}\text { as a percentage to total number } \\
\text { of postgraduate students }\end{array}$ & 14,9 & 13,6 & 12,0 & 10,7 & 9,1 \\
\hline HEE, persons & 23493 & 24625 & 22838 & 22134 & 20749 \\
\hline $\begin{array}{l}\text { as a percentage to total number } \\
\text { of postgraduate students }\end{array}$ & 85,1 & 86,4 & 88,0 & 89,3 & 90,9 \\
\hline Number of doctoral students, total persons & 1759 & 1821 & 1792 & 1646 & 1145 \\
\hline National universities, persons & 341 & 338 & 308 & 272 & 176 \\
\hline $\begin{array}{l}\text { as a percentage to total number } \\
\text { of doctoral students }\end{array}$ & 19,4 & 18,6 & 17,2 & 16,5 & 15,4 \\
\hline HEE, persons & 1418 & 1483 & 1484 & 1374 & 969 \\
\hline $\begin{array}{l}\text { as a percentage to total number } \\
\text { of doctoral students }\end{array}$ & 80,6 & 81,4 & 82,8 & 83,5 & 84,6 \\
\hline
\end{tabular}

Source: Developed by the author on the basis of ${ }^{1}$

In general, from 2014 to 2018 training of doctors of sciences in the HEE fell by $31.7 \%$ and by $48.4 \%$ in the national universities. If in 2014 one establishment had 3 candidates for the doctor's degree and 9 candidates for the degree of the candidate of sciences, in 2018 these figures fell by approximately $30 \%$. The number of candidates for the degree of the doctor of sciences per one national university fell by $37.5 \%$, and by $9.6 \%$ per one HEE. Training of postgraduate students fell by $49.6 \%$ in the national universities and by $11.7 \%$ in the HEE.

If the fall in the number of the candidates is accompanied by an increase of the effective component defense of dissertations - we can talk about the positive shifts, because most of the academic degree seekers study at the expense of the state budget and these expenses must be justified (Fig. 3 and 4).

The number of postgraduate student graduates kept on falling till 2017, but in 2018 it grew by $5.2 \%$. In doctoral studies, the breakthrough took place in 2018 with the growth of $77 \%$. Before that, starting from 2015 , there has been a reduction of the number of graduates.

The number of defended dissertation among the postgraduate students kept on falling from 2015 to 2017 , but in 2018 it slightly increased. However, their proportion fell from $24.8 \%$ in 2014 to $23 \%$ in 2018 . The defense of doctoral dissertations within five years also showed a downward trend from $27.3 \%$ in 2014 to $24.1 \%$ in 2018 . The proportion of defended dissertations here is higher than that of the post graduate students, which is explained by a more balanced approach to the choice of the research subject and presence of previous exploratory works.

\footnotetext{
${ }^{1}$ Державна служба статистики України (2020). Статистичні збірники Наукова та інноваційна діяльність в Україні за 2014-2018 pp. <http://www.ukrstat.gov.ua/druk/publicat/Arhiv_u/16/Arch_nay_zb.htm>(2020, September, 20).
} 


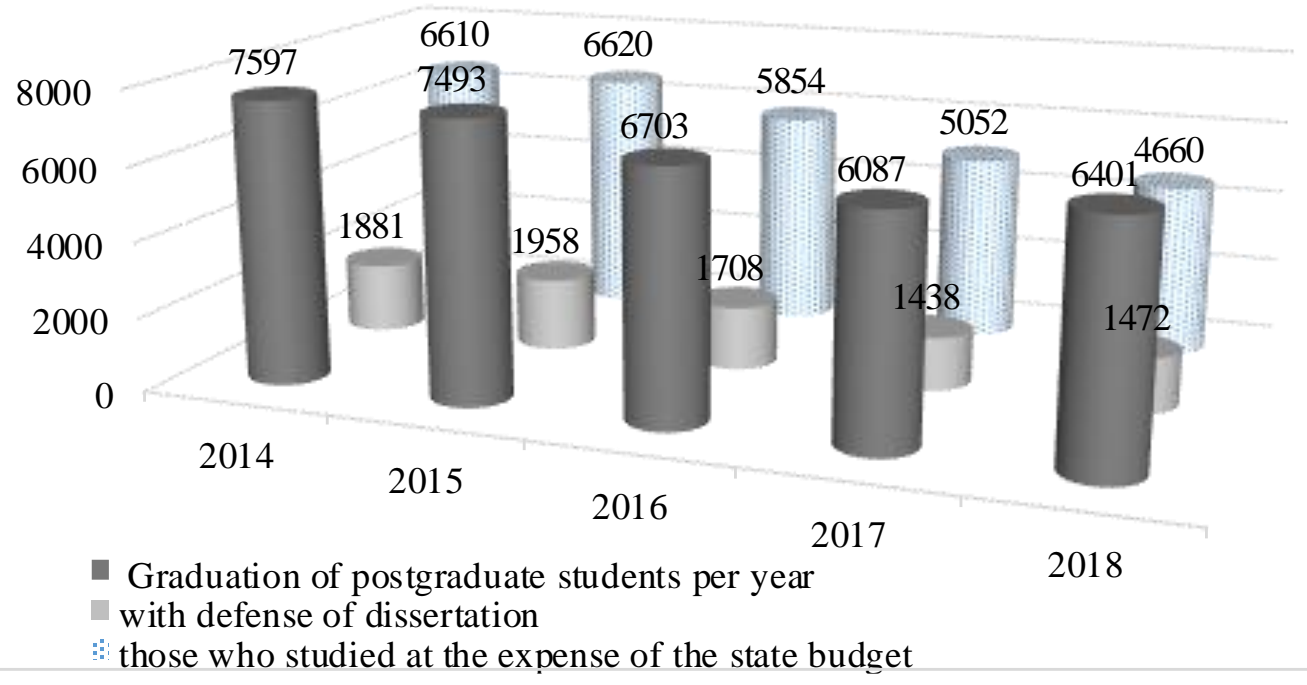

Fig. 3. Graduation of postgraduate students and the number of dissertations for the academic degree over time in 2014-2018

Source: Developed by the author on the basis of ${ }^{1}$

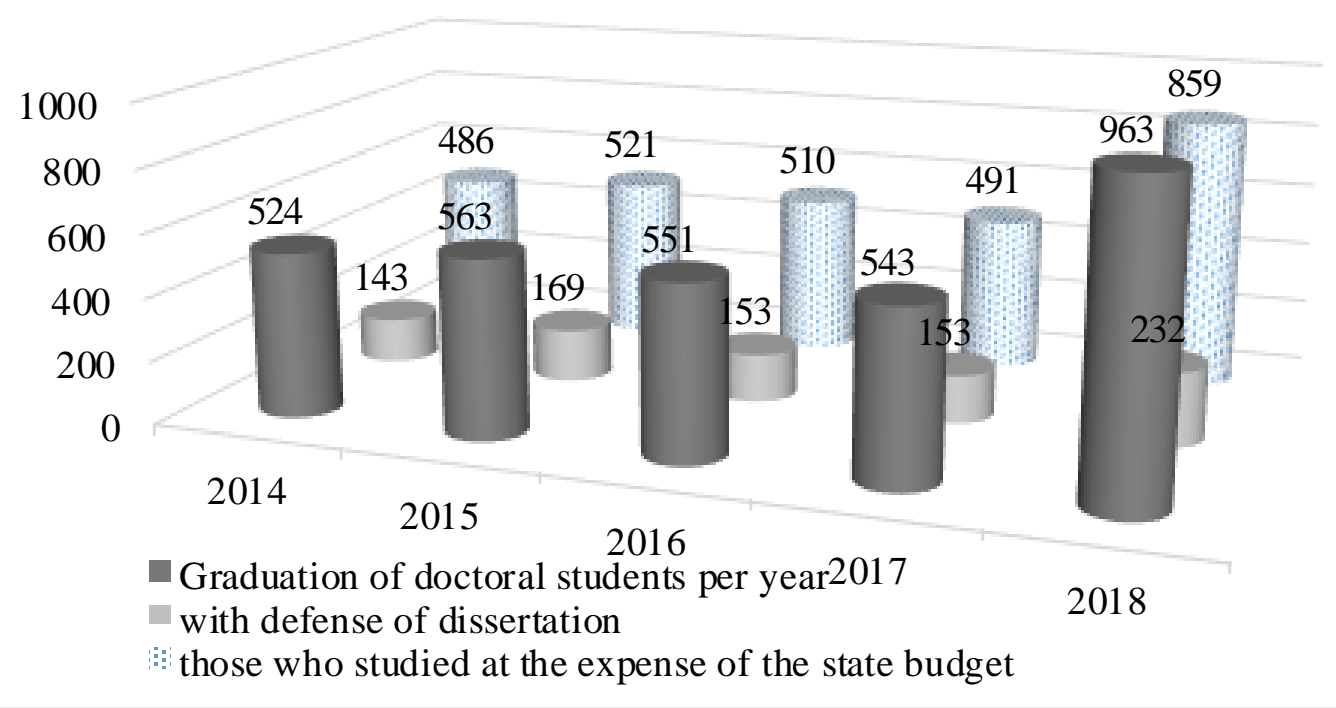

Fig. 4. Graduation of doctoral students and the number of dissertations for the academic degree over time in 2014-2018

Source: Developed by the author on the basis of

\footnotetext{
${ }^{1}$ Державна служба статистики України (2020). Статистичні збірники Наукова та інноваиійна діяльність в Україні за 2014-2018 pp. <http://www.ukrstat.gov.ua/druk/publicat/Arhiv_u/16/Arch_nay_zb.htm> (2020, September, 20).

${ }^{2}$ Ibid.
} 
Despite the declining efficiency of functioning of postgraduate and doctoral programs, the share of instructors with a scientific degree and an academic title is growing, which should indicate an improvement in the quality of instruction. However, negative comments of employers on the quality of skills and competencies of the graduates in certain areas are becoming more frequent. In our opinion, this is caused by fluctuations in the pace of development in the industries, which creates changes in the sectoral structure of employment and professional-qualification demand for the workforce and personnel retraining.

The central executive body in the field of education and science forms, periodically amends and improves the list of specialities and industries for which specialists, including the academic degree seekers, are trained in the HEE ${ }^{12}$. To adapt activities of academic staff, graduates of the previous years, to the provisions of the new list, the Ministry of Education and Science of Ukraine issued its order \#1151 "On particularities of introduction of the list of the fields of expertise and specialities in which higher education seekers are trained, approved by the Decree of the Cabinet of Ministers of Ukraine \#266 of April 29, 2015"3, whereby the tables of correspondences of scientific specialties, areas and professions in which training of higher education students was and will be carried out have been approved.

With the growing demand for specialists in a particular field of activity it should be recognized that they must be taught by the instructor competent in the relevant field. So involvement of young people in teaching activities, who have already obtained education in accordance with the updated list of industries, will help to form the appropriate skills and competencies necessary for the future graduates in line with the present day tendencies. Therefore, it is expedient to carry out a comparative analysis of the pattern of admission to and graduation from graduate/doctoral studies in relevant fields with changes in the demand of applicants for higher education depending on the labor market trends.It will show how strategically correct was the choice of academic degree seekers and those who determine the number of training of academic teaching staff through postgraduate and doctoral studies by way of budgetary funding in a particular speciality and outline the content of formation of the qualitative component of the personnel reserve.

Shortage of statistical data, or rather their detailing, holds in check implementation of such studies. For a more meaningful assessment formation of the personnel reserve it would be expedient to analyze the above indices by specialities, rather than by the fields of knowledge or sciences, because as of today graduation and defense of dissertations by the academic degree seekers under the list of 2011 still continue, but already began under the list of 2015. Admission of academic degree seekers under the new list started in 2016, therefore, the approximate period of graduation of the doctors of philosophy should have taken place in 2020, and that of the doctors of sciences in 2018. Although occasional graduations and defenses of dissertations under the new list of the fields of knowledge took place in the first years and, likewise, there continued graduations and defenses under the previous list of the fields of science. The admission of candidates for the bachelor's, specialist and master's degrees since 2016 was made exclusively under the list of the fields of knowledge 2015. The obsolete content and mechanism of statistical reporting, as well as the generalized data collection by the State Statistics Service in the fields of sciences, do not permit a detailed assessment of the quality of the supply of personnel reserve for the HEE. We can make a comparison separately by the fields of sciences and separately by the fields of knowledge (Fig. 5).

Comparing proportion of the TOP-10 fields of knowledge to which the maximum admission to the first and second cycles of higher education was made in the period 2016-2019 with the ten top most productive in terms of defense of dissertations by postgraduate and doctoral students, we see that the list of the fields of knowledge is not radically different, but they may be inferior in weight.

\footnotetext{
${ }^{1}$ Постанова про затвердження переліку галузей знань і спеціальностей, за якими здійснюється підготовка здобувачів вищої освіти, 2015 (Кабінет Міністрів України). Офіиійний сайт Кабінету Міністрів України <https://www.kmu.gov.ua/npas/248149695 >(2020, September, 20).

${ }^{2}$ Постанова про внесення змін до постанови Кабінету Міністрів Украӥни від 29 квітня 2015 р. № 266, 2017 (Кабінет Міністрів України). Офіиійний сайт Верховної Ради Украӥни <https://zakon.rada.gov.ua/laws/show/ 53-2017-\%D0\%BF\#Text >(2020, September, 20).

${ }^{3}$ Наказ про особливості запровадження переліку галузей знань і спеціальностей, за якими здійснюється підготовка здобувачів вищої освіти, затвердженого постановою Кабінету Міністрів України від 29 квітня 2015 року № 266, 2015 (Міністерство освіти та науки України). Офіиійний сайт Верховної Ради України <https://zakon.rada.gov.ua/laws/show/z1460-15\#Text>(2020, September, 20).
} 


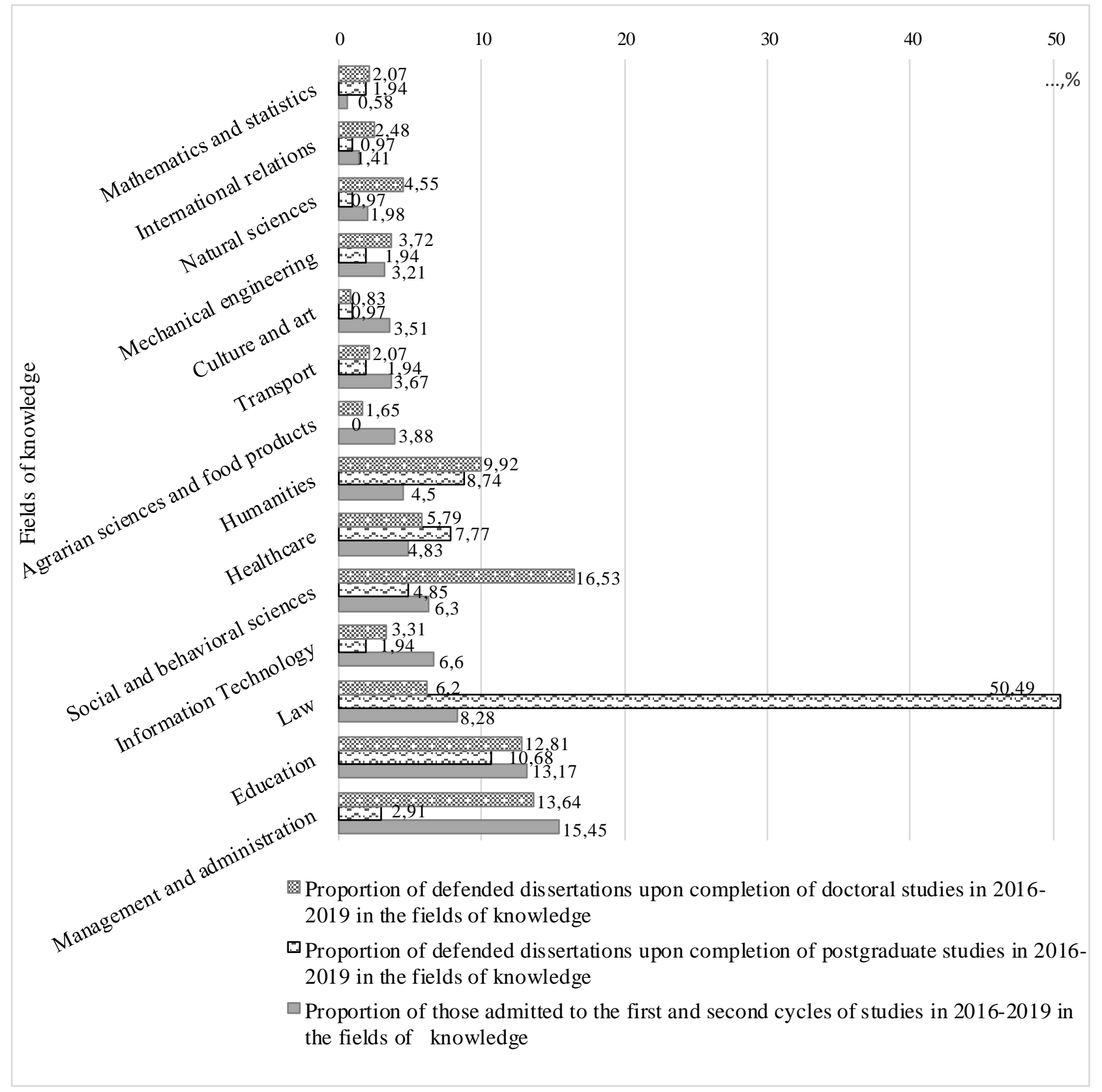

Fig. 5. Structural indices of the highest rating fields of knowledge in the period 2016-2019

Source: Developed by the author on the basis of ${ }^{1}$

Thus, in field "Agrarian sciences and food products" there were no dissertations defended for the doctor of philosophy degree in the period of 2016-2019, and in field "Culture and art" there were defended very few dissertations defended by both, postgraduate and doctoral students although both were in the top ten in terms of the number of entrants enrolled in 2016-2019. It is worth to note the low activity of applicants in such field of knowledge as "Mathematics and statistics" in contrast with the scientific activity of postgraduate and doctoral students, whose scientific achievements in this field rate exceptionally high abroad.

Redundant number of the trained academic staff in certain fields can have an adverse effect on the perspectives of employment of postgraduate and doctoral graduates. It is clear that not all of them will

\footnotetext{
${ }^{1}$ Державна служба статистики України (2020). Статистичні збірники Наукова та інноваційна діяльність в Украӥні за 2014-2018 pp. <http://www.ukrstat.gov.ua/druk/publicat/Arhiv_u/16/Arch_nay_zb.htm>(2020, September, 20).
} 
be involved in the educational process in the future, but their scholarly studies will form the theoretical basis and ensure practical development of the field.

Conclusions. Therefore for determination of the need for the formation of human resources for higher education it is necessary:

- standard numbers of those who study for the post of instructor taking into account the dependence on a speciality, educational level and the form of studies;

- academic case of a high school instructor, that may contain from one to five disciplines;

- license conditions for conducting educational activities of the HEE;

- the need for academic, academic teaching, teaching specialists in a particular field of knowledge explained not only by the demand for the speciality, but also by long- and medium-term forecasts of labor market needs;

- possibility of retraining of higher education staff on the basis of interdisciplinary integration of educational sectors.

To this end it is first of all incumbent to:

- pay more attention to explaining the proposition of higher education in the field of knowledge in comparison with the study of demand ;

- improve approaches, content and detailing of the sectoral statistical information, that would facilitate monitoring of relevant processes and adoption of sound management decisions in the process of implementation of educational reforms;

- eliminate inconsistency of the standard numbers of those who study for the full-time post of instructor in a HEE with the staff requirements to ensure educational activities in the sphere of higher education on the approved license conditions and within time limits for planning and logging of educational work of the instructors HEE.

Major changes in the world of work have had a certain impact on the career expectations of the teenagers, whose attention is more centered on fewer occupations, but still somehow coincide with the focus of academic degree students in these fields of knowledge, which characterizes best the strategy of higher education staff potential. Development of education should be carried out taking into account the correlation dependence on such value as the real need of the production sphere in intellectual and human capital, which requires further rigorous research.

\section{References:}

1. Zakon pro vyshchu osvitu, 2014 (Verkhovna Rada Ukrainy) [Law on higher education 2014 (Verkhovna Rada of Ukraine)]. Ofitsiinyi sait Verkhovnoi Rady Ukrainy [The official website of Verkhovna Rada of Ukraine]. <http://zakon4.rada.gov.ua/laws/show/1556-18/page4> (2020, September, 20). [in Ukrainian].

2. Zakon pro naukovu i naukovo-tekhnichnu diialnist, 2016 (Verkhovna Rada Ukrainy) [Law about scientific and scientific and technical activities 2016 (Verkhovna Rada of Ukraine)]. Ofitsiinyi sait Verkhovnoi Rady Ukrainy [The official website of Verkhovna Rada of Ukraine]. 〈https://zakon.rada.gov.ua/laws/show/848-19\#Text> (2020, September, 20). [in Ukrainian].

3. Zakon pro fakhovu peredvyshchu osvitu, 2019 (Verkhovna Rada Ukrainy) [Law on Professional Higher Education 2019 (Verkhovna Rada of Ukraine)]. Ofitsiinyi sait Verkhovnoi Rady Ukrainy [The official website of Verkhovna Rada of Ukraine].<https://zakon.rada.gov.ua/laws/show/2745-19\#Text> (2020, September, 20). [in Ukrainian].

4. Derzhavna sluzhba statystyky Ukrainy (2020) [State Statistics Service of Ukraine (2020)]. Statystychni zbirnyky Vyshcha osvita v Ukraini za 2015-2019 rr. [Statistical collections Higher Education in Ukraine for 2015-2019]. Ofitsiinyi sait Derzhavnoi sluzhby statystyky Ukrainy [The official website of State Statistics Service of Ukraine]. <https://ukrstat.org/uk/druk/publicat/kat_u/publosvita_u.htm> (2020, September, 20). [in Ukrainian].

5. Postanova pro vnesennia zmin do postanovy vid 30 hrudnia 2015 r. № 1187 "Pro zatverdzhennia Litsenziinykh umov provadzhennia osvitnoi diialnosti zakladiv osvity” 2018 (Kabinet Ministriv Ukrayiny) [Resolution on amendments to the resolution "On Approval of Licensing Conditions for Educational Activities of Educational Institutions", 2018 (Cabinet of Ministers of Ukraine)]. Ofitsiinyi sait Kabinetu Ministriv Ukrayiny [The official website of Cabinet of Ministers of Ukraine] 〈https://zakon.rada.gov.ua/laws/show/347-2018-\%D0\%BF\#Text> (2020, September, 20). [in Ukrainian].

6. Postanova pro normatyvy chyselnosti studentiv (kursantiv), aspirantiv (adiunktiv), doktorantiv, zdobuvachiv naukovoho stupenia kandydata nauk, slukhachiv, interniv, klinichnykh ordynatoriv na odnu shtatnu posadu naukovo-pedahohichnoho pratsivnyka u vyshchykh navchalnykh zakladakh III i IV rivnia akredytatsii ta vyshchykh navchalnykh zakladakh pisliadyplomnoi osvity derzhavnoi formy vlasnosti, 2002 (Kabinet Ministriv Ukrayiny) [Resolution on the norms of the number of students (cadets), graduate students (adjuncts), doctoral students, candidates for scientific degrees, students, interns, clinical residents for one full-time position of research and teaching staff in higher educational institutions of III and IV level of accreditation and higher educational 
institutions of postgraduate education of the state form of ownership 2002 (Cabinet of Ministers of Ukraine)]. Ofitsiinyi sait Kabinetu Ministriv Ukrayiny [The official website of Cabinet of Ministers of Ukraine] <https://zakon.rada.gov.ua/laws/show/1134-2002-\%D0\%BF\#Text> (2020, September, 20). [in Ukrainian].

7. Derzhavna sluzhba statystyky Ukrainy (2020) [State Statistics Service of Ukraine (2020)]. Statystychni zbirnyky Naukova ta innovatsiina diialnist v Ukraini za 2014-2018 r.r. [Statistical collections Scientific and innovative activities in Ukraine for 2012-2018]. Ofitsiinyi sait Derzhavnoi sluzhby statystyky Ukrainy [The official website of State Statistics Service of Ukraine]. 〈http://www.ukrstat.gov.ua/druk/publicat/Arhiv_u/16/Arch_nay_zb.htm> (2020, September, 20). [in Ukrainian].

8. Postanova pro zatverdzhennia pereliku haluzei znan i spetsialnostei, za yakymy zdiisniuietsia pidhotovka zdobuvachiv vyshchoi osvity, 2015 (Kabinet ministriv Ukrainy) [Resolution on the list of disciplines and specialties, for which training of candidates for higher education is carried (Cabinet of Ministers of Ukraine)]. Ofitsiinyi sait Kabinetu Ministriv Ukrayiny [The official website of Cabinet of Ministers of Ukraine] <https://www.kmu.gov.ua/npas/248149695> (2020, September, 20). [in Ukrainian].

9. Postanova pro vnesennia zmin do postanovy Kabinetu Ministriv Ukrainy vid 29 kvitnia 2015 r. № 266, 2017 (Kabinet ministriv Ukrainy). [Resolution on amendments to the Resolution of the Cabinet of Ministers of Ukraine dated April 29, 2015, № 2662017 (Cabinet of Ministers of Ukraine)]. Ofitsiinyi sait Verkhovnoi Rady Ukrainy [The official website of Verkhovna Rada of Ukraine]. 〈https://zakon.rada.gov.ua/laws/show/53-2017-\%D0\%BF\#Text> (2020, September, 20). [in Ukrainian].

10. Nakaz pro osoblyvosti zaprovadzhennia pereliku haluzei znan $i$ spetsialnostei, za yakymy zdiisniuietsia pidhotovka zdobuvachiv vyshchoi osvity, zatverdzhenoho postanovoiu Kabinetu Ministriv Ukrainy vid 29 kvitnia 2015 roku \# 266, 2015 (Ministerstvo osvity ta nauky Ukrainy) [Decree on the list of branches of knowledge and specialties according to which preparation of higher education candidates is carried out, approved by the resolution of the Cabinet of Ministers of Ukraine dated April 29, 2015. No. 2662017 (Ministry of Education and Science of Ukraine)]. Ofitsiinyi sait Verkhovnoi Rady Ukrainy [The official website of Verkhovna Rada of Ukraine].

<https://zakon.rada. gov.ua/laws/show/z1460-15> (2020, September, 20). [in Ukrainian]. 